ISSN 1392-3196 / e-ISSN 2335-8947

Zemdirbyste-Agriculture, vol. 105, No. 2 (2018), p. 183-190

DOI $10.13080 / \mathrm{z}-\mathrm{a} .2018 .105 .024$

\title{
Genetic diversity of populations of Bidens genera invasive and native species in Lithuania
}

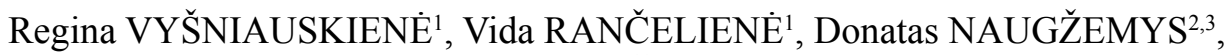 \\ Jolanta PATAMSYTE ${ }^{2}$, Zofija SINKEVIČIENE ${ }^{1}$, Jurgita BUTKUVIENE ${ }^{2}$, Donatas ŽVINGILA ${ }^{2}$ \\ ${ }^{1}$ Nature Research Centre \\ Akademijos 2, Vilnius, Lithuania \\ ${ }^{2}$ Life Sciences Center, Vilnius University \\ Saulètekio 7, Vilnius, Lithuania \\ E-mail: donatas.zvingila@gf.vu.lt \\ ${ }^{3}$ Botanical Garden of Vilnius University \\ Kairènu 43, Vilnius, Lithuania
}

\begin{abstract}
River riparian ecosystems deteriorate because of anthropogenic factors that are related to industry, intensive agriculture and tourism. Two native species, Bidens tripartita and B. cernua, are weeds widespread in Lithuania on river banks and other habitats. An alien species, $B$. frondos $a$, is also widespread in the same habitats. We investigated the genetic diversity of $B$. frondosa, compared its population structure to that of related species and assessed the possibility of genetic interaction between $B$. frondosa and native congeners. Genetic analysis of populations was based on inter-simple sequence repeats (ISSR) polymorphism. Our results revealed high genetic differentiation in the $B$. frondosa populations $(48.2 \%)$ and high genotypic diversity $(\mathrm{i}=0.99)$. Bayesian cluster analysis using the program Structure revealed signs of gene flow between $B$. frondosa and the native species; however, principal coordinate analysis did not support this result. Our results do not indicate the role of interspecific hybridization in the invasiveness of $B$. frondosa.
\end{abstract}

Key words: Bidens, hybridization, invasive species, population genetic structure.

\section{Introduction}

Human-mediated changes in the river environment create favourable conditions for non-native species introduction, long-term settlement and spread (Richardson et al., 2007). The spread of alien plant species in the new area can endanger or even destroy the integrity of natural communities because of the negative effects of invaders on native species and ecosystem stability (Pauchard, Alaback, 2004). It may initiate evolution of weed communities and appearance of new weeds in agroecosystems (Danuso et al., 2012). Rivers are important corridors for alien plant dissemination because propagules can be carried along the river by water, wind, humans and animals (Johansson et al., 1996; Richardson et al., 2007). High levels of disturbance that are typical of river banks in anthropogenically affected territories are also beneficial for the establishment of newcomers. Two annual species of the genus Bidens (B. cernua L. and $B$. tripartita L.) are native to Lithuania and common in riverside plant communities. The non-native congener B. frondosa L. was first observed in 1983 in the middle reaches of the Nemunas River and recently has become widespread along this river and its tributaries and on the shores of the Curonian Lagoon (Gudžinskas, 1997; 2003). Quite often, this species occurs in the wet forests or in human-modified habitats (Gudžinskas, 1997).

$B$. frondosa is considered one of the most invasive species in Europe (Lambdon et al., 2008), and recently, this plant species has been included in the list of invasive plants of Lithuania. In some European countries this species is known as agricultural and environmental weed (Groves, 1999). B. frondosa spreads in arable fields of North Italy and is frequently found in summer crops (sugarbeet, maize, etc.). In Lithuania, B. frondosa and its close relative $B$. tripartita are weeds that are usually found in uncultivated areas (Čiuberkis, Vilkonis, 2013).

In Europe, $B$. frondosa was introduced from North America, where its native range occupies a large territory extending from Alaska into the central part of the continent. Supposedly $B$. frondosa, as with some other invasive plants, escaped from European botanical

Please use the following format when citing the article:

Vyšniauskienė R., Rančelienė V., Naugžemys D., Patamsytė J., Sinkevičienė Z., Butkuvienė J., Žvingila D. 2018. Genetic diversity of populations of Bidens genera invasive and native species in Lithuania. Zemdirbyste-Agriculture, 105 (2): $183-190$ DOI 10.13080/z-a.2018.105.024 
gardens and spread into natural ecosystems (Galkina et al., 2015). The intensive expansion of this weed began after World War II, and the species became naturalized in many European countries (Chytrý et al., 2008), as well as in Lithuania (Gudžinskas, 1997; 2003). B. frondosa produces many seeds, which adhere to the surface of animal fur or human clothing and can be easily dispersed over long distances. The river water flow is also an important factor in the seed dispersal of $B$. frondosa (Kostrakiewicz-Gieralt, Zając, 2014). B. frondosa has a highly flexible vegetative phase and can grow taller and produce more seeds than its congener, B. tripartita (Danuso et al., 2012). In parts of Europe, B. frondosa has displaced the native $B$. tripartita and $B$. cernua in some habitats (Vinogradova et al., 2014). According to the literature, the impact of alien species on native plant communities and native congeners could be dual: ecological - out-competed native species, and genetic interspecific hybridization between the invader and native species (Bleeker et al., 2007). Interspecific hybridization is known to sometimes produce genotypes with increased weedy properties and invasiveness (Ellstrand, Schierenbeck, 2000). The genetic impact of $B$. frondosa on the native species is controversial because plants of intermediate morphology have been found in natural ecosystems; however, no proof of hybridization has been obtained for the studied genotypes (Crowe, Parker, 1981; Vinogradova et al., 2014; Galkina et al., 2015). The analysis of the genetic structure of invasive populations of $B$. frondosa has not received sufficient attention until now and is limited to a genetic diversity analysis of a small number of genotypes (Galkina et al., 2015).

The aim of our study was (1) to explore Bidens frondosa population structure and genetic diversity measures and compare these parameters to those of two native species $B$. tripartita and B. cernua and (2) to determine if a genetic interaction exists between $B$. frondosa and the native species.

\section{Materials and methods}

Plant materials. Populations were studied in river ecosystems that were considered possible corridors for the spread of Bidens frondosa in Lithuania. The study was performed in 2015-2016. On the river banks, $B$. frondosa grows as big stands near water. B. frondosa, $B$. tripartita and $B$. cernua plants were collected on the Nemunas, Neris, Vokè, Nevéžis and Jiesia rivers, and lagoon shores (Fig. 1).

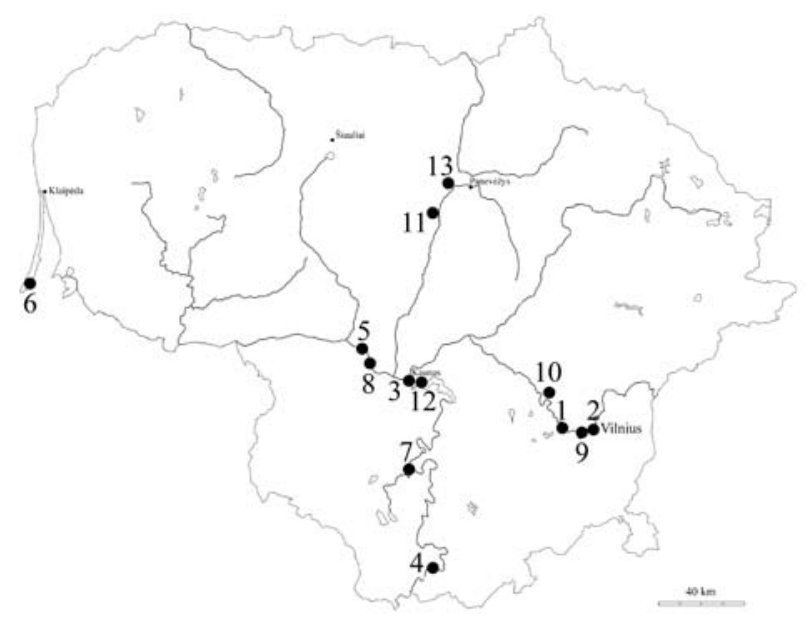

Note. The sites indicated by the numbers as in Table 1.

Figure 1. Geographic location of the sample collection sites of Bidens species in Lithuania

A total of 286 plants were collected from 23 populations in 13 different sites (Table 1).

Samples of $B$. frondosa were gathered randomly with a minimal distance between samples of at least 8-10 metres. The number of $B$. frondosa plants collected per population ranged between 6 and 20. The native

Table 1. Collection sites and habitats of Bidens frondosa and its congeneric native species, B. tripartita and B. cernua

\begin{tabular}{|c|c|c|c|c|c|c|}
\hline $\begin{array}{l}\text { Site } \\
\text { No. }\end{array}$ & Site name & Bidens species & $\begin{array}{l}\text { Latitude, } \\
\text { N }\end{array}$ & $\begin{array}{c}\text { Longitude, } \\
\text { E }\end{array}$ & Habitats & River \\
\hline \multirow[t]{3}{*}{1.} & Grigiškès & B. frondosa & $54^{\circ} 40^{\prime} 21^{\prime \prime}$ & $25^{\circ} 05^{\prime} 08^{\prime \prime}$ & Riverside, near gardens & Vokè \\
\hline & & B. tripartita & $54^{\circ} 39^{\prime} 55^{\prime \prime}$ & $25^{\circ} 06^{\prime} 12^{\prime \prime}$ & & \\
\hline & & B. cernua & $54^{\circ} 39^{\prime} 55^{\prime \prime}$ & $25^{\circ} 06^{\prime} 12^{\prime \prime}$ & & \\
\hline \multirow[t]{2}{*}{2.} & Vilnius & B. frondosa & $54^{\circ} 41^{\prime} 41^{\prime \prime}$ & $25^{\circ} 18 ’ 05^{\prime \prime}$ & Riverside, city centre & Neris \\
\hline & & B. tripartita & $54^{\circ} 41^{\prime} 20^{\prime \prime}$ & $25^{\circ} 17 ’ 29 ”$ & & \\
\hline \multirow[t]{3}{*}{3.} & Kaunas & B. frondosa & $54^{\circ} 53^{\prime} 36^{\prime \prime}$ & $23^{\circ} 53^{\prime} 33^{\prime \prime}$ & Riverside, city centre & Nemunas \\
\hline & & B. tripartita & $54^{\circ} 53^{\prime} 34^{\prime \prime}$ & $23^{\circ} 53^{\prime} 47^{\prime \prime}$ & & \\
\hline & & B. cernua & $54^{\circ} 53$ '34”' & $23^{\circ} 53^{\prime} 47^{\prime \prime}$ & & \\
\hline \multirow[t]{3}{*}{4.} & Druskininkai & B. frondosa & $54^{\circ} 01^{\prime} 24^{\prime \prime}$ & $23^{\circ} 58^{\prime} 35^{\prime \prime}$ & Riverside, city centre & Nemunas \\
\hline & & B. tripartita & $54^{\circ} 01^{\prime} 24^{\prime \prime}$ & $23^{\circ} 58^{\prime} 35^{\prime \prime}$ & & \\
\hline & & B. cernua & $54^{\circ} 01^{\prime} 24^{\prime \prime}$ & $23^{\circ} 58^{\prime} 35^{\prime \prime}$ & & \\
\hline \multirow[t]{2}{*}{5.} & Vilkija & B. frondosa & $55^{\circ} 02^{\prime} 32^{\prime \prime}$ & $23^{\circ} 33^{\prime} 53^{\prime \prime}$ & Riverside, near path & Nemunas \\
\hline & & B. tripartita & $55^{\circ} 02^{\prime} 38^{\prime \prime}$ & $23^{\circ} 33^{\prime} 17^{\prime \prime}$ & & \\
\hline \multirow[t]{2}{*}{6.} & Nida & B. frondosa & $55^{\circ} 19^{\prime} 02^{\prime \prime}$ & $21^{\circ} 01^{\prime} 14^{\prime \prime}$ & Curonian lagoon & \\
\hline & & B. cernua & $55^{\circ} 19^{\prime} 02^{\prime \prime}$ & $21^{\circ} 01^{\prime} 14^{\prime \prime}$ & & \\
\hline 7. & Merkinė & B.frondosa & $54^{\circ} 09^{\prime} 29^{\prime \prime}$ & $24^{\circ} 09^{\prime 2} 29^{\prime \prime}$ & Riverside near bridge & Nemunas \\
\hline 8. & Kulautuva & B. frondosa & $54^{\circ} 566^{\prime} 27^{\prime \prime}$ & $23^{\circ} 37^{\prime} 46^{\prime \prime}$ & Riverside, landing-place & Nemunas \\
\hline 9. & Žvėrynas & B. frondosa & $54^{\circ} 41^{\prime} 36^{\prime \prime}$ & $25^{\circ} 14 ’ 19^{\prime \prime}$ & Riverside near buildings & Neris \\
\hline 10. & Šilènai & B. frondosa & $54^{\circ} 43211^{\prime \prime}$ & $25^{\circ} 022^{\prime} 49^{\prime \prime}$ & Riverside near angler path & Neris \\
\hline 11. & Krekenava & B. frondosa & $55^{\circ} 32^{\prime} 11^{\prime \prime}$ & $24^{\circ} 05^{\prime 2} 29^{\prime \prime}$ & Riverside near grassland and the bush & Nevėžis \\
\hline \multirow[t]{2}{*}{12.} & Jiesia & B. tripartita & $54^{\circ} 51^{\prime} 26^{\prime \prime}$ & $23^{\circ} 55^{\prime} 52^{\prime \prime}$ & Riverside near path & Jiesia \\
\hline & & B. cernua & $54^{\circ} 51$ '29”' & $23^{\circ} 56^{\prime} 02^{\prime \prime}$ & & \\
\hline 13. & Varpučiai & B. frondosa & $55^{\circ} 43^{\prime} 10^{\prime \prime}$ & $24^{\circ} 13$ '34” & Riverside, livestock watering-place & Nevėžis \\
\hline
\end{tabular}


populations of $B$. tripartita and B. cernua are also spread in the riverside habitats. $B$. tripartita and $B$. cernua population samples were collected from areas where the plants were intermixed with $B$. frondosa (both native species in Druskininkai) and from areas where they grow in the vicinity (B. tripartita in Grigiškès or B. cernua in Vilkija) or grow separately (B. tripartita and $B$. cernua in Jiesia) from $B$. frondosa. In some collection sites, only the invasive $B$. frondosa was found (Table 1).

DNA extraction and inter-simple sequence repeats-polymerase chain reaction (ISSR-PCR). Total genomic plant DNA was extracted from the dried leaves. DNA extraction and purification was performed using the Genomic DNA Purification Kit, K0152 (Thermo Fisher Scientific Baltics, Lithuania), according to the manufacturer's instructions. The concentration and quality of the DNA samples were assessed spectrophotometrically and by electrophoresis on agarose gels.

ISSR polymorphism was assessed using four primers previously used by Tanahara and Maki (2010) in Bidens studies. ISSR-PCR with these primers produced clear and reproducible patterns of DNA bands in agarose gels. The ISSR-PCR reaction mixtures had a total volume of $10 \mu \mathrm{l}$. The reaction mixtures contained $0.5 \mathrm{U}$ of recombinant Taq DNA polymerase (Thermo Fisher Scientific Baltics), $0.1 \mu \mathrm{M}$ primer (Biomers, Germany), $0.2 \mathrm{mM}$ of each dNTP, $1 \times$ Taq buffer with $\left(\mathrm{NH}_{4}\right)_{2} \mathrm{SO}_{4}$ (Thermo Fisher Scientific Baltics), $2.5 \mathrm{mM} \mathrm{MgCl}_{2}$ and $10 \mathrm{ng}$ of template DNA. Amplification was performed in a thermocycler (Biometra $\mathrm{GmbH}$, Germany) programmed as follows: $4 \mathrm{~min}$ at $95^{\circ} \mathrm{C}$ for the initial denaturation, 45 cycles of $30 \mathrm{~s}$ at $95^{\circ} \mathrm{C}$ (denaturation), $45 \mathrm{~s}$ at $50^{\circ} \mathrm{C}$ (annealing) and $2 \mathrm{~min}$ at $72^{\circ} \mathrm{C}$ (extension). The final reaction extension step was carried out at $72^{\circ} \mathrm{C}$ for $5 \mathrm{~min}$ (Tanahara, Maki, 2010). The reproducibility of the DNA band patterns of the studied genotypes was tested by repeating experiments at least twice. ISSR-PCR products were separated on $1.5 \%$ agarose gels in $0.5 \times$ TAE buffer under conditions of constant voltage of $4.0 \mathrm{~V} \mathrm{~cm}^{-1}$ for $3.5 \mathrm{~h}$. The size of the scored DNA fragments was estimated with the DNA band size standard GeneRuler $1 \mathrm{~kb}$ DNA Ladder (Thermo Fisher Scientific Baltics) using software BioDocAnalyze (Biometra).

Statistical analysis. ISSR polymorphisms data generated from 286 individual plants were scored into a binary matrix according to the absence $(0)$ or presence (1) of ISSR fragments. An analysis of molecular variance (AMOVA) was carried out using software GenAlEx v.6.5 (Peakall, Smouse, 2012). Based on the DNA band presence / absence binary matrix, the expected heterozygosity $(\mathrm{Hj})$ was calculated using program $A F L P$ -
SURV v.1.0 (Vekemans et al., 2002). AFLP-SURV v.1.0 was also used to evaluate the genetic differentiation (Fst - fixation index) among populations. A significance test for Fst was based on 1000 permutations. The percentage of polymorphic bands (PLP), the polymorphic band proportion at the 5\% level (PLP 5\%) and band richness (Br) were calculated in program AFLPdiv v.1.1 (Coart et al., 2005) for five individuals per population used for rarefaction. Shannon's diversity index (I) was calculated using software POPGENE v.1.32 (Yeh et al., 1997). Genotypic diversity was assessed by calculating the proportion of distinguishable genotypes: $i=G / N$, where $\mathrm{G}$ is the number of genotypes, and $\mathrm{N}$ - the total number of studied individuals. The hierarchical AMOVA was performed in software GenAlEx v.6.5 (Peakall, Smouse, 2012) to evaluate partitioning of diversity within ( $\left.\mathrm{Phi}_{\mathrm{PT}}\right)$ and among $\left(\mathrm{Phi}_{\mathrm{RT}}\right)$ species. The significance test for variance components was based on 999 permutations. In addition, we used principal coordinates analysis (PCoA) implemented in software GenAlEx v. 6.5 to evaluate the relations among the populations. A software package TREECON for Windows was used to evaluate the genetic distances among genotypes and identify the identical genotypes (Van De Peer, De Wachter, 1994). To assess genetic structures of Bidens species population and allocate genotypes to clusters, we performed Bayesian cluster analysis using the program Structure v.2.3.4. The "admixture" model was chosen for analysis. After a period of testing (500 000 cycles), $500000 \mathrm{MCMC}$ repetitions were done for a number of clusters $(\mathrm{K})$ ranging from one to 23 .

We used the Mann-Whitney $U$ test for a standardized sample size (five individuals from each population) and population number (six populations per species) to investigate whether statistically significant differences existed among the population diversity measures of $B$. frondosa, B. tripartita and B. cernua. The statistical analysis was performed using software $I B M^{\mathbb{B}}$ SPSS ${ }^{\circledR}$ Statistics v.23 for Windows.

\section{Results}

Molecular diversity at the species level. We scored 85 reproducible polymorphic DNA bands that were generated with four primers. A similar number of polymorphic DNA bands were detected in ISSR profiles of studied species: $B$. frondosa -71 , B. tripartita -72 and $B$. cernua -71 . On average, 18 bands were identified with one primer for each species. The sizes of the DNA fragments used for analysis were 250-2000 bp (Table 2).

Table 2. ISSR primers used for analysis of Bidens species and the number of identified DNA bands per primer

\begin{tabular}{lcccc}
\hline \multirow{2}{*}{ Sequence (5'-3') } & \multicolumn{3}{c}{ DNA bands (polymorphic bands) in ISSR profiles } \\
\cline { 2 - 4 } & B. frondosa & B. tripartita & B. cernua & Size range (bp) \\
\hline (AG) ${ }_{8}$ TC & $17(16)$ & $18(18)$ & $21(21)$ & $450-2000$ \\
$(\mathrm{GACA})_{4}$ & $18(18)$ & $18(18)$ & $17(16)$ & $250-1300$ \\
$(\mathrm{CTC})_{4}$ CRC & $19(19)$ & $20(20)$ & $22(22)$ & $250-2000$ \\
SSWN(GACA) & $18(18)$ & $17(16)$ & $14(12)$ & $250-2000$ \\
\hline \multicolumn{1}{c}{ Total } & $72(71)$ & $73(72)$ & $74(71)$ & $18.50 \pm 3.62$ \\
\hline \multicolumn{1}{c}{ Mean \pm SE } & $18 \pm 0.8$ & $18.25 \pm 0.25$ & \\
\hline
\end{tabular}

$\mathrm{SE}$ - standard error 
However, the number of studied individuals of $B$. frondosa was more than three times larger (185) than that of B. tripartita (54) and B. cernua (47). Only two genotypes among $185 \mathrm{~B}$. frondosa samples were detected in duplicate. So, the genotypic diversity of $B$. frondosa was high (i=0.99). Among $47 \mathrm{~B}$. cernua individuals, the number of identical genotypes was higher: one genotype was detected in three individuals, and two genotypes were detected in two individuals. All 54 studied B. tripartita plants were genetically different.

ISSR polymorphism within the $B$. frondosa populations. The average percentage of polymorphic bands (PLP) in B. frondosa populations was $34.4 \pm 3.0$, the average expected heterozygosity $(\mathrm{Hj})-0.124 \pm 0.01$ and the average value of Shannon's index (I) $-0.161 \pm$ 0.015 (Table 3).

Table 3. Summary of Bidens frondosa, B. tripartita and B. cernua populations genetic diversity estimates

\begin{tabular}{|c|c|c|c|c|c|c|c|c|c|}
\hline No. & Population & IDpop & $\mathrm{N}$ & $\operatorname{loc} \mathrm{P}$ & PLP & $\mathrm{Hj}$ & I & $\mathrm{Br}(5)$ & PLP 5\% (5) \\
\hline \multicolumn{10}{|c|}{ Bidens frondosa } \\
\hline 1. & GrigiškèsF & $1 \mathrm{~F}$ & 17 & 36 & 42.4 & 0.159 & 0.226 & 1.320 & 0.424 \\
\hline 2. & VilniusF & $2 \mathrm{~F}$ & 15 & 28 & 32.9 & 0.122 & 0.168 & 1.245 & 0.329 \\
\hline 3. & KaunasF & $3 \mathrm{~F}$ & 17 & 17 & 20 & 0.070 & 0.094 & 1.142 & 0.200 \\
\hline 4. & DruskininkaiF & $4 \mathrm{~F}$ & 20 & 33 & 38.8 & 0.128 & 0.167 & 1.263 & 0.388 \\
\hline 5. & VilkijaF & $5 \mathrm{~F}$ & 15 & 31 & 36.5 & 0.141 & 0.164 & 1.281 & 0.365 \\
\hline 6. & NidaF & $6 \mathrm{~F}$ & 18 & 49 & 57.6 & 0.197 & 0.265 & 1.404 & 0.576 \\
\hline 7. & MerkinėF & $7 \mathrm{~F}$ & 16 & 26 & 30.6 & 0.098 & 0.121 & 1.205 & 0.306 \\
\hline 8. & KulautuvaF & $8 \mathrm{~F}$ & 17 & 23 & 27.1 & 0.101 & 0.124 & 1.203 & 0.271 \\
\hline 9. & ŽvėrynasF & $9 \mathrm{~F}$ & 12 & 27 & 31.8 & 0.114 & 0.141 & 1.235 & 0.318 \\
\hline 10. & ŠilènaiF & $10 \mathrm{~F}$ & 15 & 33 & 38.8 & 0.154 & 0.202 & 1.307 & 0.388 \\
\hline 11. & KrekenavaF & $11 \mathrm{~F}$ & 17 & 32 & 37.6 & 0.124 & 0.174 & 1.256 & 0.376 \\
\hline 12. & VarpučiaiF & $12 \mathrm{~F}$ & 6 & 16 & 18.8 & 0.079 & 0.089 & 1.171 & 0.188 \\
\hline & Mean & & 15.4 & 29.3 & 34.4 & 0.124 & 0.161 & 1.253 & 0.344 \\
\hline & $\mathrm{SE}$ & & 1.0 & 2.5 & 3.0 & 0.010 & 0.015 & 0.020 & 0.030 \\
\hline \multicolumn{10}{|c|}{ Bidens tripartita } \\
\hline 13. & GrigiškėsT & $1 \mathrm{~T}$ & 9 & 41 & 48.2 & 0.200 & 0.261 & 1.404 & 0.482 \\
\hline 14. & VilniusT & $2 \mathrm{~T}$ & 5 & 15 & 17.6 & 0.081 & 0.078 & 1.176 & 0.176 \\
\hline 15. & KaunasT & $3 \mathrm{~T}$ & 19 & 58 & 68.2 & 0.256 & 0.345 & 1.511 & 0.682 \\
\hline 16. & DruskininkaiT & $4 \mathrm{~T}$ & 6 & 37 & 43.5 & 0.204 & 0.244 & 1.414 & 0.435 \\
\hline 17. & VilkijaT & $5 \mathrm{~T}$ & 9 & 24 & 28.2 & 0.104 & 0.121 & 1.217 & 0.282 \\
\hline 18. & JiesiaT & $6 \mathrm{~T}$ & 6 & 20 & 23.5 & 0.101 & 0.131 & 1.216 & 0.235 \\
\hline & Mean & & 9.0 & 32.5 & 38.2 & 0.158 & 0.197 & 1.323 & 0.382 \\
\hline & $\mathrm{SE}$ & & 2.1 & 6.5 & 7.7 & 0.029 & 0.042 & 0.056 & 0.077 \\
\hline \multicolumn{10}{|c|}{ Bidens cernua } \\
\hline 19. & GrigiškèsC & $1 \mathrm{C}$ & 21 & 27 & 31.8 & 0.123 & 0.179 & 1.249 & 0.365 \\
\hline 20. & KaunasC & $2 \mathrm{C}$ & 5 & 39 & 45.9 & 0.239 & 0.269 & 1.459 & 0.459 \\
\hline 21. & DruskininkaiC & $3 \mathrm{C}$ & 10 & 31 & 36.5 & 0.174 & 0.202 & 1.329 & 0.365 \\
\hline 22. & NidaC & $4 \mathrm{C}$ & 6 & 24 & 28.2 & 0.130 & 0.255 & 1.265 & 0.282 \\
\hline 23. & JiesiaC & $5 \mathrm{C}$ & 5 & 21 & 24.7 & 0.102 & 0.126 & 1.247 & 0.247 \\
\hline \multicolumn{3}{|c|}{ Mean } & 9.4 & 28.4 & 33.4 & 0.153 & 0.206 & 1.310 & 0.344 \\
\hline \multicolumn{3}{|c|}{$\mathrm{SE}$} & 3.0 & 3.1 & 3.7 & 0.025 & 0.026 & 0.040 & 0.037 \\
\hline
\end{tabular}

IDpop - short population name, $\mathrm{N}$ - the number of analysed plants per population, loc $\mathrm{P}-$ the number of polymorphic bands, $\mathrm{PLP}$ - the percentage of polymorphic bands, $\mathrm{Hj}$ - expected heterozygosity, I - Shannon's index of genetic diversity, $\mathrm{Br}(5)$ - band richness with sample size rarefied to five individuals, PLP 5\% (5) - polymorphic band proportion with sample size rarefied to five individuals at the $5 \%$ level; SE - standard error

The average number of identified polymorphic bands in $B$. frondosa populations was $29.3 \pm 2.5$. The lowest genetic diversity measures were found in the $12 \mathrm{~F}$ population $(\mathrm{PLP}=18.8, \mathrm{Hj}=0.079, \mathrm{I}=0.089)$; the highest were found in the Nida population (PLP $=57.6, \mathrm{Hj}=$ $0.197, \mathrm{I}=0.265)$. The genetic diversity measures $(\mathrm{Hj}$ and PLP) in the $B$. frondosa population did not correlate with the number of analysed individuals $(p>0.05)$. When the number of individuals per population was rarefied to five individuals per population, the same tendency was noted for the genetic diversity distribution in the populations. The highest proportion of polymorphic bands was detected in the $6 \mathrm{~F}$ population (PLP $5 \%=0.576, \mathrm{Br}=1.404)$, and the lowest, in the $12 \mathrm{~F}$ (PLP $5 \%=0.188$ ), except for the $\mathrm{Br}$ measure, which was least in the $3 \mathrm{~F}$ population $(\mathrm{Br}=$ 1.142). Although the 3F population of $B$. frondosa formed a large stand, with 17 individuals being collected for analysis, only 20 polymorphic bands were identified in the studied genotypes. The highest measures of genetic diversity among the studied species were revealed in B. tripartita: $\operatorname{loc} \mathrm{P}=32.5, \mathrm{PLP}=38.2, \mathrm{Hj}=0.158, \mathrm{I}=0.197$, $\operatorname{Br}(5)=1.323$ and PLP 5\% (5) = 3.82 (Table 3).

When the numbers of populations and individuals were approximated for all species (5-6 populations per species, 47 individuals per species), the measures of genetic diversity of $B$. frondosa decreased to 24 polymorphic bands per population $(\mathrm{PLP}=28.2, \mathrm{Hj}=$ 0.11 , data not shown). Nevertheless, the Mann-Whitney test did not reveal significant differences between species in these measures.

Comparison of population genetic structures. The molecular genetic diversity analysis $(A M O V A)$ of the 23 populations revealed high differentiation among the populations $\left(\mathrm{Phi}_{\mathrm{PT}}=0.636, p<0.001\right)$. Analysis showed that $36 \%$ of the genetic diversity was located within populations (Table 4).

Similar results were generated with the program $A F L P-S U R V$ (Fst $=0.59 \pm 0.04)$. An assessment of the 
Table 4. Molecular variance among and within Lithuanian populations of three Bidens species according to ISSR markers

\begin{tabular}{|c|c|c|c|c|c|c|}
\hline $\begin{array}{c}\text { Source of } A M O V A \\
\text { of all populations }\end{array}$ & df & SS & MS & $\begin{array}{c}\text { Total variance } \\
\% \\
\end{array}$ & $\mathrm{Phi}_{\mathrm{PT}}$ & $p$ \\
\hline Among species & 2 & 958.985 & 479.492 & 33 & & \\
\hline Among pops & 20 & 1343.380 & 67.169 & 30 & & \\
\hline Within pops & 263 & 1581.338 & 6.013 & 36 & & \\
\hline Total & 285 & 3883.703 & & 100 & 0.636 & $<0.001$ \\
\hline $\begin{array}{l}\text { B. frondosa } \\
\text { Among pops } \\
\text { Within pops }\end{array}$ & $\begin{array}{c}11 \\
173\end{array}$ & $\begin{array}{l}881.742 \\
906.441 \\
\end{array}$ & $\begin{array}{c}80.158 \\
5.240\end{array}$ & $\begin{array}{l}48 \\
52\end{array}$ & & \\
\hline Total & 184 & 1788.184 & & 100 & 0.482 & $<0.001$ \\
\hline $\begin{array}{l}\text { B. tripartita } \\
\text { Among pops } \\
\text { Within pops }\end{array}$ & $\begin{array}{c}5 \\
48 \\
\end{array}$ & $\begin{array}{l}208.773 \\
373.227\end{array}$ & $\begin{array}{c}41.755 \\
7.776\end{array}$ & $\begin{array}{l}34 \\
66\end{array}$ & & \\
\hline Total & 53 & 582.000 & & 100 & 0.339 & $<0.001$ \\
\hline $\begin{array}{l}\text { B. cernua } \\
\text { Among pops } \\
\text { Within pops }\end{array}$ & $\begin{array}{c}4 \\
42\end{array}$ & $\begin{array}{l}204.875 \\
257.976\end{array}$ & $\begin{array}{c}51.219 \\
6.142\end{array}$ & $\begin{array}{l}47 \\
53\end{array}$ & & \\
\hline Total & 46 & 462.851 & & 100 & 0.466 & $<0.001$ \\
\hline
\end{tabular}

$\mathrm{df}-$ degree of freedom, $\mathrm{SS}$ - sum of squares, MS - mean squares, $\mathrm{Phi}_{\mathrm{PT}}-$ genetic differentiation among populations, $p$ - significance level

partitioning of the genetic variability within species revealed genetic differentiation that was somewhat greater among populations of $B$. frondosa $\left(P h i_{\mathrm{PT}}=0.482\right.$, $p<0.001)$ compared with B. cernua $\left(P h i_{\mathrm{PT}}=0.466\right.$ $p<0.001)$ and considerably higher than the genetic differentiation existing among populations of $B$. tripartita $\left(P h i_{\mathrm{PT}}=0.339, p<0.001\right)$. Hierarchical $A M O V A$ was performed to establish the variance component among species. Populational diversity accounted for $33 \%$ of the differences between species.

The results of principal coordinates analysis (PCoA), disclosing the relations between $B$. frondosa and the two native species, are shown as a two-dimensional plot (Fig. 2). The first two coordinates in the PCoA explained $46.97 \%$ of the variance. In this analysis, individuals of the different species were organized into distinct groups, and no overlapping groups were seen as potential hybrids.

We used the Bayesian procedure provided by the program Structure to elucidate the population structures in three species. The analysis grouped all populations into the two most likely clusters $(\mathrm{K}=2)$ (Fig. 3A).

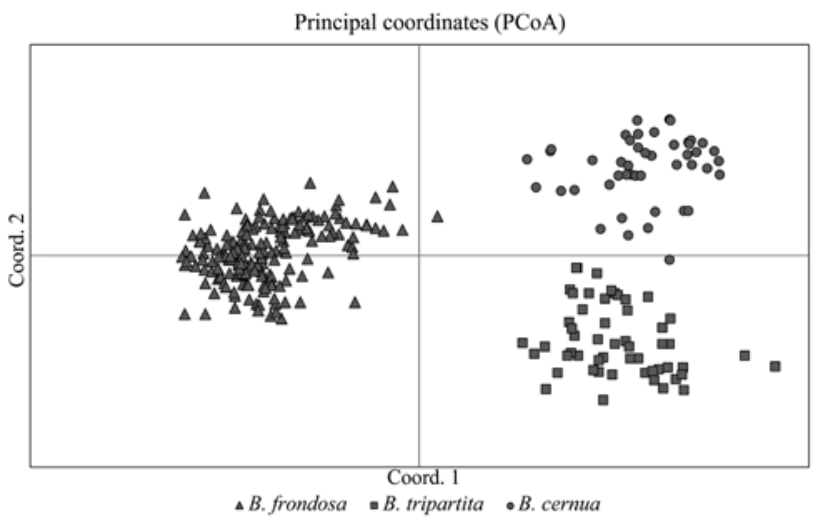

Figure 2. Two-dimensional plot envisioning relationships between Bidens species

Cluster 1 (white) included all B. frondosa populations. Cluster 2 (black) contained populations of the two native species. The smaller peak was detected at $\mathrm{K}=3$. In this case, the clustering corresponded to $B$. frondosa, B. tripartita and B. cernua. The assignment of populations in three clusters largely corroborated
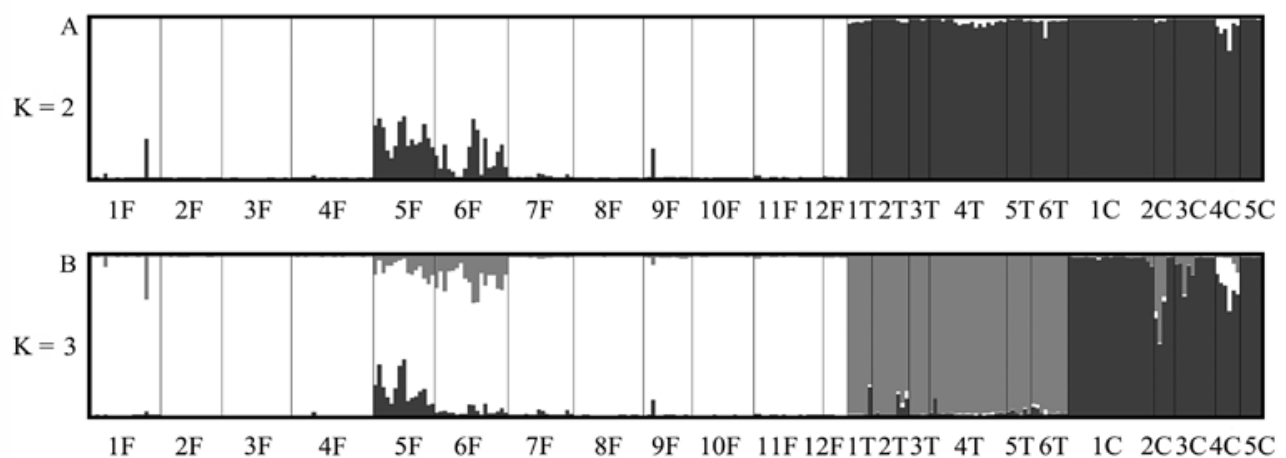

Note. The clusters are denoted by white, grey and black; individuals are represented by vertical white, grey or black bars; populations are separated by vertical black lines; populations: $1 \mathrm{~F}-12 \mathrm{~F}-$ B. frondosa, $1 \mathrm{~T}-6 \mathrm{~T}-$ B. tripartita, $1 \mathrm{C}-5 \mathrm{C}-$ B. cernua .

Figure 3. Likelihood of the groupings of Bidens frondosa, B. tripartita and B. cernua plants to the genetic clusters $(\mathrm{K}=2$ and $\mathrm{K}=3)$ identified by the Bayesian clustering method 
the results of the PCoA. However, the Bayesian analysis revealed two admixed populations ( $5 \mathrm{~F}$ and $6 \mathrm{~F}$ ) of B. frondosa (Fig. 3B). Certain signs of admixture were seen in some populations of the native species. However, in general, most populations were genetically homogeneous.

\section{Discussion}

An analysis of the genetic diversity of invasive species populations is a relevant topic for invasion biology as it provides a basis for a more reliable assessment of the species evolutionary potential in the new range, and a better understanding of invasion mechanisms and history and can contribute to more effective species control measures (Wang et al., 2012; Shou-Li et al., 2016). Bidens frondosa intensively spreads in Lithuania, especially in riparian habitats. According to theory, the introduction of an alien species is usually associated with founding events (Novak, Mack, 2005; Dlugosch, Parker, 2008) that later can be counteracted by multiple introductions, genetic recombination and other mechanisms (Bossdorf et al., 2005; Kelager etal., 2013). Unfortunately, we cannot assess how much genetic diversity was lost or acquired during the invasion process because we did not have information about the genetic diversity of the B.frondosa native populations. Nevertheless, we attempted to compare the level of diversity with that of two related native species. A comparison of diversity parameters among related species with different breeding system (Sun, Wong, 2001), native and invasive (Beckmann etal., 2009), common and endangered (Tanahara, Maki, 2010; Chung et al., 2012), endemic and widespread (Bednarska, Brazauskas, 2017) is a widely accepted approach in population ecology. We identified high genotypic diversity among the studied $B$. frondosa plants. Only a few genotypes were found to be duplicated, which, considering the sampling strategy, indicates the absence of large clones in the $B$. frondosa populations. A similar level of genetic diversity was established in populations of the native B. cernua and B. tripartita (Tanahara, Maki, 2010). No statistically significant differences were detected in the genetic diversity measures among the three Bidens species. The percentage of polymorphic bands for $B$. cernua and $B$. tripartita in our study was similar to that in the study of Tanahara and Maki (2010), except that we found slightly higher ISSR polymorphism in $B$. tripartita, whereas in the previous study, this polymorphism was higher in B. cernua.

In summary, our results indicate high genotypic and genetic diversity in the studied populations of $B$. frondosa in spite of rather short invasion history. The genetic differences among the $B$. frondosa populations $\left(B f \mathrm{Phi}_{\mathrm{PT}}=0.482\right)$ were only slightly higher than in native congener $\left(B c \mathrm{Phi}_{\mathrm{PT}}=0.466, B t \mathrm{Phi}_{\mathrm{PT}}=0.339\right)$. Similar values of genetic differentiation observed among populations of $B$. cernua $\left(\mathrm{Phi}_{\mathrm{PT}}=0.438\right)$ and $B$. tripartita $\left(\mathrm{Phi}_{\mathrm{PT}}=0.413\right)$ in Japan are described in a previous study (Tanahara, Maki, 2010). Rather high genetic variability of $B$. frondosa populations could indicate that introductions from different source populations contributed to the current pattern of genetic structure in the invasive species (Durka et al., 2005; Kupcinskiene et al., 2013; Patamsyte et al., 2013).

A threat of invasive species is the genetic corruption of the native species by gene flow and hybridization (Ellstrand, Schierenbeck, 2000; Bleeker et al., 2007), and many studies have reported genetic assimilation and loss of integrity in native species
(Bleeker et al., 2007; Schierenbeck, Ellstrand, 2009; Vyšniauskienè et al., 2015). The structure analysis of the studied Bidens populations showed signs of admixture in some populations of $B$. frondosa and in some populations of the native species (Fig. 3).

Interestingly, our results indicate a possible larger impact of the native species on the $B$. frondosa than vice versa. The genetic structures of the $5 \mathrm{~F}$ and $6 \mathrm{~F}$ populations of $B$. frondosa show signs of introgression from $B$. cernua and $B$. tripartita. Overlapping of ranges from biological invasion makes hybridization of related species possible. B. frondosa produces pollen of high viability; however, at least in part of genotypes the usual fertilization is rare and gene flow between $B$. frondosa and related species is problematic because of the different ploidies of these species (Crowe, Parker, 1981). Crowe and Parker (1981) considered B. connata a possible hybrid between $B$. frondos $a$ and $B$. cernua; however, they did not find reliable evidence for this hypothesis. Few works about potential $B$. frondosa hybrids with other related species are reviewed in Vinogradova et al. (2014). The most recent information on this topic is provided from studies in the upper basin of Volga on potential hybrids by V. G. Papchenkov and other Russian botanists, which were critically revised by Vinogradova et al. (2014) and Galkina et al. (2015). Based on morphological and molecular (ISSR) data analysis, these authors concluded that low hybridogenic activity existed with $B$. frondosa. Knope et al. (2013) also studied the hybridization between alien and native Bidens species. They hybridized $B$. alba and $B$. pilos $a$ with nine native Hawaiian species and did not obtain viable hybrids. In our study, principal coordinate analysis of the three Bidens species populations, based on the molecular diversity patterns, did not show an overlap between species in the two coordinate systems (Fig. 2) and do not indicate intermediate genotypes; this outcome agrees with the results of Galkina et al. (2015).

The morphological characteristics of the plants involved in our study from populations that, according to Bayesian cluster analysis, are characterized as admixed and possess genetic material from genepools of different species, did not attract our attention as having discrepancies from the typical morphology of $B$. frondosa. In addition, $A M O V A$ also showed significant differentiation between Bidens species $\left(\mathrm{Phi}_{\mathrm{RT}}=0.33\right)$. These results, taken together, also support the absence of genetic interactions between $B$. frondos $a$ and native species.

Intensive studies of plant invasion phenomena revealed plant characteristics that are favourable for invasiveness (Rejmánek, 1996; Bossdorf et al., 2005). High seed production and ecological plasticity are characteristic of B. frondosa (Danuso et al., 2012). Ellstrand and Schierenbeck (2000) proved that interspecific hybridization is also an important mechanism for invasiveness as it increases genetic variation and produces genotypes with new characteristics. High genetic diversity also is favourable for the adaptation and spread of alien plants (Lavergne, Molofsky, 2007).

\section{Conclusion}

In the current study, we detected comparatively high genotypic and genetic diversity of invasive Bidens frondosa that is comparable with similar parameters of native species $B$. cernua and $B$. tripartita. The analysis of the population genetic structure of $B$. frondosa indicates that hybridization with native species, if this process occurs at all, is not an important factor for invasiveness. 


\section{Acknowledgements}

This research was funded by a grant (No. SIT2/2015) from the Research Council of Lithuania.

Received 25102017

Accepted 22032018

\section{References}

1. Beckmann M., Erfmeier A., Bruelheide H. 2009. A comparison of native and invasive populations of three clonal plant species in Germany and New Zealand. Journal of Biogeography. 36: 865-878. https://doi.org/10.1111/j.1365-2699.2008.02048.x

2. Bednarska I., Brazauskas G. 2017. Festuca galiciensis, a new species of the $F$. valesiaca group (Poaceae) from Ukraine. Phvtotaxa. 306: 21-36.

https://doi.org/10.11646/phytotaxa.306.1.2

3. Bleeker W., Schmitz U., Ristow M. 2007. Interspecific hybridisation between alien and native plant species in Germany and its consequences for native biodiversity. Biological Conservation. 137: 248-253. https://doi.org/10.1016/j.biocon.2007.02.004

4. BossdorfO., Auge H., Lafuma L., Rogers W. E., Siemann E., Prati D. 2005. Phenotypic and genetic differentiation between native and introduced plant populations. Oecologia, 144: $1-11$. https://doi.org/10.1007/s00442-005-0070-z

5. Chung M. Y., López-Pujol J., Maki M., Kim K. J., Chung J. M., Sun B. Y., Chung M. G. 2012. Genetic diversity in the common terrestrial orchid Oreorchis patens and its rare congener Oreorchis coreana: inference of species evolutionary history and implications for conservation. Journal of Heredity, 103: 692-702. https://doi.org/10.1093/jhered/ess032

6. Chytrý M., Maskell L. C., Pino J., Pyšek P., Vilà M., Font X., Smart S. M. 2008. Habitat invasions by alien plants: a quantitative comparison among Mediterranean, subcontinental and oceanic regions of Europe. Journal of Applied Ecology, 45: 448-458. https://doi.org/10.1111/j.1365-2664.2007.01398.x

7. Coart E., Van Glabeke S., Petit R. J., Van Bockstaele E., Roldán-Ruiz I. 2005. Range wide versus local patterns of genetic diversity in hornbeam (Carpinus betulus L.). Conservation Genetics. 6: 259-273. https://doi.org/10.1007/s10592-004-7833-7

8. Crowe D. R., Parker W. H. 1981. Hybridization and agamospermy of Bidens in Northwestern Ontario. Taxon, 30: 749-760. https://doi.org/10.2307/1220076

9. Ciuberkis S., Vilkonis K. K. 2013. Weeds in agroecosystems of Lithuania. Lithuanian Research Centre for Agriculture and Forestry, 256 p. (in Lithuanian).

10. Danuso F., Zanin G., Sartorato I. 2012. A modelling approach for evaluating phenology and adaptation of two congeneric weeds (Bidens frondosa and Bidens tripartita). Ecological Modelling. 243: 33-41. https://doi.org/10.1016/j.ecolmodel.2012.06.009

11. Dlugosch K. M., Parker I. M. 2008. Founding events in species invasions: genetic variation, adaptive evolution, and the role of multiple introductions. Molecular Ecology, 17: 431-449. https://doi.org/10.1111/j.1365-294X.2007.03538.x

12. Durka W., Bossdorf O., Prati D., Auge H. 2005. Molecular evidence for multiple introductions of garlic mustard (Alliaria petiolata, Brassicaceae) to North America. Molecular Ecologv. 14: 1697-1706.

https://doi.org/10.1111/j.1365-294X.2005.02521.x

13. Ellstrand N. C., Schierenbeck K. A. 2000. Hybridization as a stimulus for the evolution of invasiveness in plants. Proceedings of the National Academy of Sciences of the United States of America. 97 (13): 7043-7050. https://doi.org/10.1073/pnas.97.13.7043
14. Galkina M. A., Vinogradova Yu. K., Shanzer I. A. 2015. Biomorphological features and microevolution of the invasive species Bidens L. in European Russia. Biology Bulletin. 42 (4): 315-325. https://doi.org/10.1134/S1062359015040056

15. Groves R. H. 1999. Keynote address: environmental weeds - past, present and future. Plant Protection Quarterly, 14 (3): 92-95.

16. Gudžinskas Z. 1997. Conspectus alien plant species of Lithuania. 4. Asteraceae. Botanica Lithuanica, 3 (4): 335-366.

17. Gudžinskas Z., Kull T., Tabaka L. 2003. Bidens L. Kuusk V. et al. (eds). Flora of the Baltic Countries, 3: 184-186.

18. Johansson M. E., Nilsson Ch., Nilsson E. 1996. Do rivers function as corridors for plant dispersal? Journal of Vegetation Science, 7: 593-598.

https://doi.org/10.2307/3236309

19. Kelager A., Pedersen J. S., Bruun H. H. 2013. Multiple introductions and no loss of genetic diversity: invasion history of Japanese Rose, Rosa rugosa, in Europe. Biological Invasions, 15 (5): 1125-1141. https://doi.org/10.1007/s10530-012-0356-0

20. Knope M., Pender R., Craword D., Wieczorek A. 2013. Invasive congeners are unlikely to hybridize with native Hawaiian Bidens (Asteraceae). American Journal of Botany, 100 (6): 1221-1226. https://doi.org/10.3732/ajb.1300018

21. Kostrakiewicz-Gieralt K., Zając M. 2014. The influence of habitat conditions on the performance of two invasive, annuals - Impatiens glandulifera and Bidens frondosa. Biologia, 69: 449-462. https://doi.org/10.2478/s11756-014-0333-4

22. Kupcinskiene E., Zybartaite L., Janulioniene R., Zukauskiene J., Paulauskas A. 2013. Molecular diversity of small balsam populations in relation to site characteristics. Central European Journal of Biology, 8: 1048-1061. https://doi.org/10.2478/s11535-013-0228-3

23. Lambdon P. W., Pyšek P., Basnou C., Hejda M., Arianoutsou M., Essl F., Jarošik V., Pergl J., Winter M., Anastasiu P., Andriopoulos P., Bazos I., Brundu G., Celesti-Grapow L., Chassot P., Delipetrou P., Josefsson M., Kark S., Klotz S., Kokkoris Y., Kuhn I., Marchante H., Perglova I., Pino J., Vila M., Zikos A., Roy D., Hulme Ph. E. 2008. Alien flora of Europe: species diversity, temporal trends, geographical patterns and research needs. Preslia, 80: 101-149. http://www.preslia.cz/P082Lam.pdf

24. Lavergne S., Molofsky J. 2007. Increased genetic variation and evolutionary potential drive the success of an invasive grass. Proceedings of the National Academy of Sciences of the United States of America. 104: 3883-3888. https://doi.org/10.1073/pnas.0607324104

25. Novak S. J., Mack R. N. 2005. Genetic bottlenecks in alien plant species: influence of mating systems and introduction dynamics. Sax D. F. et al. (eds). Species invasions: insights into ecology, evolution, and biogeography, p. 201-228.

26. Patamsytè J., Čèsnienè T., Naugžemys D., Kleizaitė V., Tunaitienė V., Vaitkūnienè V., Rančelis V., Mikaliūnaitė R., Žvingila D. 2013. Different habitats show similar genetic structure of Bunias orientalis L. (Brassicaceae) in Lithuania. Notulae Botanicae Horti Agrobotanici ClujNapoca, 41: 396-403. https://doi.org/10.15835/nbha4129186

27. Pauchard A., Alaback P. B. 2004. Influence of elevation, land use, and landscape context on patterns of alien plant invasions along roadsides in protected areas of south-central Chile. Conservation Biology, 18 (1): 238-248. https://doi.org/10.1111/j.1523-1739.2004.00300.x

28. Peakall R., Smouse P. E. 2012. GenAlEx 6.5: genetic analysis in Excel. Population genetic software for teaching and research - an update. Bioinformatics. 28: 2537-2539. https://doi.org/10.1093/bioinformatics/bts460

29. Rejmánek M. 1996. A theory of seed plant invasiveness: the first sketch. Biological Conservation, 78 (1-2): 171-181. https://doi.org/10.1016/0006-3207(96)00026-2 
30. Richardson D. M., Holmes P. M., Esler K. J., Galatowitsch S. M., Stromberg J. C., Kirkman S. P., Pysek P., Hobbs R. J. 2007. Riparian vegetation: degradation, alien plant invasions, and restoration prospects. Diversity and Distributions, 13: 126-139.

https://doi.org/10.1111/j.1366-9516.2006.00314.x

31. Schierenbeck K. A., Ellstrand N. C. 2009. Hybridization and the evolution of invasiveness in plants and other organisms. Biological Invasions, 11: 1093-1105.

https://doi.org/10.1007/s10530-008-9388-x

32. Shou-Li L., Vasemägi A., Ramula S. 2016. Genetic variation and population structure of the garden escaper Lupinus polyphyllus in Finland. Plant Systematics and Evolution, 302: 399-407.

https://doi.org/10.1007/s00606-015-1273-3

33. Sun M., Wong K. C. 2001. Genetic structure of three orchid species with contrasting mating systems using RAPD and allozyme markers. American Journal of Botany, 88: 2180 2188. https://doi.org/10.2307/3558379

34. Tanahara A., Maki M. 2010. Genetic diversity and population genetic differentiation in the endangered annual weed, Bidens cernua (Compositae), and two common congeners in Japan. Weed Biology and Management, 10: $113-119$. https://doi.org/10.1111/j.1445-6664.2010.00374.x

35. Van De Peer Y., De Wachter R. 1994. TREECON for Windows: a software package for the construction and drawing of evolutionary trees for the Microsoft Windows environment. Computer Applications in the Biosciences, 10: $569-570$.

https://doi.org/10.1093/bioinformatics/10.5.569
36. Vekemans X., Beauwens T., Lemaire M., Roldán-Ruiz I. 2002. Data from amplified fragment length polymorphism (AFLP) markers show indication of size homoplasy and of a relationship between degree of homoplasy and fragment size. Molecular Ecology, 11: 139-151.

https://doi.org/10.1046/j.0962-1083.2001.01415.x

37. Vinogradova Yu. K., Galkina M. A., Mayorov S. R. 2014. Variability of the taxa of the Bidens L. genera and the problem of hybridization. Russian Journal of Biological Invasions, 5 (1): 1-11. https://doi.org/10.1134/S2075111714010111

38. Vyšniauskienė R., Naugžemys D., Patamsyte J., Rančelienè V., Čèsnienè T., Žvingila D. 2015. ISSR and chloroplast DNA analyses indicate frequent hybridization of alien Medicago sativa subsp. sativa and native M. sativa subsp. falcata. Plant Systematics and Evolution, 301: 2341-2350. https://doi.org/10.1007/s00606-015-1232-z

39. Wang X. Y., Shen D. W., Jiao J., Xu N. N., Yu S., Zhou X. F., Shi M. M., Chen X. Y. 2012. Genotypic diversity enhances invasive ability of Spartina alterniflora. Molecular Ecology, 21: $2542-2551$. https://doi.org/10.1111/j.1365-294X.2012.05531.x

40. Yeh F. C., Yang R. C., Boyle T. B. J., Ye Z. H., Mao J. X. 1997. POPGENE, the user-friendly shareware for population genetic analysis. Molecular Biology and Biotechnology Centre, University of Alberta, Canada.

ISSN 1392-3196 / e-ISSN 2335-8947

Zemdirbyste-Agriculture, vol. 105, No. 2 (2018), p. 183-190

DOI 10.13080/z-a.2018.105.024

\title{
Bidens genties invazinių ir vietinių Lietuvos rūšių populiacijų genetinè ịvairovè
}

\author{
R. Vyšniauskienè ${ }^{1}$, V. Rančelienė ${ }^{1}$, D. Naugžemys ${ }^{2,3}$, J. Patamsyte் ${ }^{2}$, Z. Sinkevičiené $\dot{1}^{1}$ \\ J. Butkuvienè $\dot{e}^{2}$ D. Žvingila ${ }^{2}$
}

${ }^{1}$ Gamtos tyrimų centro Botanikos institutas

${ }^{2}$ Vilniaus Universiteto Gyvybès mokslų centras

${ }^{3}$ Vilniaus universiteto Botanikos sodas

\section{Santrauka}

İvairūs antropogeniniai veiksniai (intensyvi ūkinė veikla, turizmas, klimato kaita ir kt.) pažeidžia upių ekosistemas, sudarydami sąlygas plisti invaziniams augalams. Lietuvoje upių, ypač Nemuno, ir kitų vandens telkinių pakrantėse sparčiai plinta invazinis ilgakotis lakišius (Bidens frondosa L.). Ši rūšis sąveikauja su vietinèmis rūšimis ir dažniausiai jas išstumia. Upių pakrantėse ir kitose natūraliose bei antropogenizuotose augavietėse paplitusios dvi vietinès lakišiaus rūšys - triskiautis $(B$. tripartita) ir pelkinis (B cernua). Triskiautis lakišius yra žinomas ir kaip laukų bei daržų piktžolè. $B$. frondosa kai kuriose Europos šalyse irgi yra laikoma dirbamų laukų piktžole. Siekiant nustatyti, kokie genetiniai veiksniai gali būti palankūs plisti ilgakočiui lakišiui, tirta ir palyginta šių trijų rūšių populiacijų genetinè sandara bei įvairovè. DNR polimorfizmas buvo nustatytas paprastụjų pasikartojančių sekų intarpu (angl. inter-simple sequence repeats - ISSR) metodu.

Tyrimo rezultatai parodè didelę $B$. frondosa populiacijų genetinę diferenciaciją ir genotipų ịvairovę. Nors Bayeso klasterių analizé, atlikta programa Structure, rode tam tikrus genų srauto tarp rūšių požymius, tačiau pagrindinių koordinačių analizè šio rezultato nepatvirtino. Tyrimo rezultatai parodè, kad tarprūšinè hibridizacija nèra B. frondosa invazyvumo priežastis. Šiai svetimkraštei rūšiai plisti palankus veiksnys gali būti didelè populiacijų genetinè ir genotipinè ịvairovè.

Reikšminiai žodžiai: Bidens, hibridizacija, invazinès rūšys, populiacijų genetinė sandara. 